Agro-Science Journal of Tropical Agriculture, Food, Environment and Extension Volume 15 Number 3 (September 2016) pp. 18 - 29

ISSN 1119-7455

\title{
EFFECT OF TILLAGE, RHIZOBIUM INOCULATION IN MAIZE-SOYBEAN- BASED CROPPING SYSTEMS AND NITROGEN FERTILIZER APPLICATION ON CHEMICAL FERTILITY STATUS OF SAVANNA ALFISOL, NIGERIA
}

\author{
Omeke, J.O. \\ National Agricultural Extension and Research Liaison Services, \\ Ahmadu Bello University, P.M.B. 1067, Zaria, Nigeria \\ Author’s email: obia.joe@gmail.com
}

\begin{abstract}
Field experiment was conducted at Research Farm of Institute for Agricultural Research, Ahmadu Bello University, Samaru, Nigeria, to investigate the effect of tillage, rhizobium inoculation in maize-soybeanbased cropping systems and nitrogen fertilizer application on chemical fertility status of a savanna Alfisol. The study was split-split plot design with three replications using improved soybean variety (TGX-1448-2E) and maize (SAMMAZ 14). The treatments were two tillage practices (reduced and conventional tillage) as main plot, four rhizobium inoculation in soybean-maize-based cropping systems (inoculated soybean-maize intercrop, uninoculated soybean-maize intercrop, inoculated soybean-maize rotation and uninoculated soybean-maize rotation) as sub-plot and four nitrogen fertilizer rates $\left(0,40,80\right.$ and $\left.120 \mathrm{~kg} \mathrm{~N} \mathrm{ha}{ }^{-1}\right)$ as sub-sub plot. At harvest, soil samples were taken from each of the experimental plots and analyzed for selected soil chemical properties. Soil organic carbon, total nitrogen, soil pH, available phosphorus and exchangeable bases were consistently higher under reduced tillage (RT) than under conventional tillage (CT). Soil organic carbon, total nitrogen, soil $\mathrm{pH}$, available phosphorus and exchangeable bases were significantly higher under rhizobium inoculated soybean-maize rotation compared to other cropping systems. A significant difference was found among the effect of nitrogen rates on soil organic carbon, total nitrogen, soil pH, available phosphorus and exchangeable potassium which were significantly lower under $0 \mathrm{~kg} \mathrm{~N} \mathrm{ha}{ }^{-1}$. The study demonstrated that integration of rhizobium inoculated soybean in soybean-maize-based cropping systems under tillage practices, especially $R T$ would improves chemical fertility status of the soil and subsequently reduced $\mathrm{N}$ application rate from 120 to $80 \mathrm{~kg} \mathrm{~N} \mathrm{ha-1}^{-1}$.
\end{abstract}

Key words: tillage, rhizobium inoculation, cropping systems, Nitrogen fertilizer, chemical fertility, Alfisol

\section{INTRODUCTION}

Soil is an important natural resource for agricultural and industrial development of any nation. Some of its numerous uses include the provision of anchorage for growing plants, and supply of nutrients and water to crops. The quality of soil for agricultural production depends on its sustainable supply of plant nutrients, air and water. Unfortunately, due to several anthropogenic and natural factors, most soils have become degraded, with a consequent reduction in quality. The development of resilient production systems, such as cropping systems, appropriate tillage practices and use of internal soil resources, helps to reduce soil degradation and enhance its chemical fertility status (Omeke, 2016).

Declining productivity of Nigerian Savanna soils due to continuous cropping under conventional tillage is posing a threat to the sustainability of maize-based cropping systems. Soil chemical fertility problem is widely perceived and regarded as a major limitation to increasing crop yields and a peril to sustainable maize-based cropping systems (Nkhuzenje et al., 2002). The use of chemical fertilizer is one of the conventional ways of managing soil infertility problem, but it has longterm effects on soil productivity. Its use has two major shortcomings: the inability of smallholder and resource-poor farmers to procure the fertilizer, and soil acidification (Jou et al., 1997). According to Cassman and Pingali (1995), fertilizer alone cannot sustain crop yield. In continuous maize cropping with two to three crops grown annually, for example, the use of $\mathrm{N}$ fertilizer increases with time but the yields often remain stagnant or decrease (Nkhuzenje et al., 2002). This implies that higher fertilizer use and sustainable cropping system would produce the same yield level; and that decline in yield is a response to nutrient deficiency, possibly due to overuse of fertilizer or cultivation practice. 
There are many chemical fertility constraints associated with conventional tillage system, especially when done without the basic information on soil resource sustainability. Conventional tillage causes soil crusting and compaction, associated with shallow rooting depth and leading to land degradation, decreased agricultural productivity (Ofori, 1993) and consequently, high production cost. The development of agronomic systems and tillage practices that adequately address these problems will contribute significantly to increasing soil productivity. This calls for a shift from conventional tillage to conservation-reduced tillage, with the inclusion of legume inoculated with rhizobium in maize-based cropping systems, either in rotation or intercropping, to prevent adverse ecological impact. In this regard, incorporation of soybean inoculated with rhizobium in maize-based cropping systems can help supply nutrients for sustaining soil chemical fertility, especially nitrogen, which is a critical nutrient in maize production.

Legumes-cereal rotation or intercrop is often practised so as to make cereal benefit from the significant roles of legumes in maintaining soil fertility (Amusat et al., 2014) and productivity. Rhizobium-inoculated soybean in cropping systems under minimum soil disturbances can meet most of the crop's $\mathrm{N}$ needs and contribute to soil $\mathrm{N}$ through a symbiotic nitrogen fixation. Legumes have been shown to reduce $\mathrm{N}$ fertilizer application in maize production by $18-68 \mathrm{~kg} \mathrm{~N} \mathrm{ha}^{-1}$, when compared to fallow system (Petrickova, 1992). Studies have indicated that legumes can fix up to $450 \mathrm{~kg} \mathrm{~N} \mathrm{ha}^{-1}$ year $^{-1}$ under optimal field conditions (Giller, 2001). Also, legume fixed between 16 to $50 \mathrm{~kg} \mathrm{~N} \mathrm{ha}^{-1}$ of their total $\mathrm{N}$ and had an estimated $\mathrm{N}$ contribution to soil ranging from -22 to $3 \mathrm{~kg} \mathrm{~N}^{-1}$ depending on the ratio of $\mathrm{N}$ derived from atmosphere and $\mathrm{N}$ harvest index (Yusuf et al., 2009). However, optimum legume N-benefits can only be achieved in the presence of efficient rhizobial strains, which can be native to the soil or introduced in the form of commercial inoculants. Studies in the northern Guinea savanna of Nigeria with respect to soil fertility problems included responses to inoculation with rhizobium (Sanginga, 2003; Vanlauwe et al., 2003; Okogun et al., 2005) and nitrogen fertilizer and legume-rotation effect on maize performance (Yusuf et al., 2009). But there is little information on the incorporation of legumes inoculated with rhizobia in the dominant cropping systems under different tillage practices in combination with nitrogen fertilizer application. The current research, therefore, sought to investigate the effect of tillage; in combination with soybean inoculated with rhizobium in soybean-maize-based cropping systems and nitrogen fertilizer application on chemical fertility status of Nigerian Savanna Alfisol.

\section{MATERIALS AND METHODS \\ Study Area}

A field study was conducted at the Research Farm of the Institute for Agricultural Research, Ahmadu Bello University (IAR/ABU), Samaru, Zaria during the 2011 and 2012 cropping seasons. The research field was located within longitudes $11^{\circ} 11^{\prime} \mathrm{N}$ and latitudes $007^{\circ} 37^{\prime} \mathrm{E}$ (Fig. 1). Samaru is on a mean elevation of $686 \mathrm{~m}$ above sea level and is located in the Northern Guinea savanna ecological zone of Nigeria. The area received a total rainfall of 1207 $\mathrm{mm}$ in 2011 and $1333 \mathrm{~mm}$ in 2012. The decadal rainfall data for the two years (Fig. 2) were obtained from the Meteorological Unit of the Institute for Agricultural Research, Ahmadu Bello University, Samaru, Zaria. The weather station is located about $100 \mathrm{~m}$ away from the experimental field. The decadal rainfall data obtained for both seasons fell within the long-term range, with temperature of $21.05^{\circ} \mathrm{C}$ (minimum) and $33.47^{\circ} \mathrm{C}$ (maximum) and annual rainfall of $1011 \pm 161 \mathrm{~mm}$. The main soil sub-group is Typic Haplustalf (Awujoola, 1979) or Chromic Cambisols according to the FAO system of soil classification (FAO, 2001).

The experiment was a split plot arrangement in a randomized complete block design with three replicates in both 2011 and 2012 cropping seasons. The 2011 field experiment was established mainly to create enabling soil environment to carry out effect of the following rhizobium inoculation in soybean-maize-based cropping systems; inoculated rotation, uninoculated rotation, inoculated intercrop and uinoculated intercrop in 2012 field experiment. It was for this reason that no soil and plant samples were collected in 2011. The treatments were tillage practice (reduced and conventional tillage) as main plot, rhizobium inoculation in four soybean-maizebased cropping systems (inoculated soybean-maize intercrop, uninoculated soybean-maize intercrop, inoculated soybean-maize rotation and uninoculated soybean-maize rotation) as sub plot as well as four $\mathrm{N}$ fertilizer rates $\left(0,40,80\right.$ and $\left.120 \mathrm{~kg} \mathrm{~N} \mathrm{ha}^{-1}\right)$. The conventional tillage (CT) was manually ridged at $0.75 \mathrm{~m}$ row spacing using the hoe and remoulded at 8 weeks after sowing. For reduced tillage (RT) treated seeds were sown directly without ridging at $0.75 \mathrm{~m}$ spacing between the rows after the field was demarcated into plots. Each plot, $6 \mathrm{~m} \times 5 \mathrm{~m}$, had eight 5-m long ridges, and a total of 96 plots were used for the study. The intercropping system was maize/soybean intercrop in the order of 2 rows maize to 2 rows soybean (2:2); this was maintained for both seasons. The crop rotation system was soybean-maize rotation, with soybean planted in 2011 (1:0), followed by maize in $2012(0: 1)$. Soybean (TGx 1448-2E) and maize (SAMMAZ 14) were used as test crops. However, no plant residues management after harvest was employed in both seasons rather the residues were completely removed by farmers within the location as fire wood and animal folder (feeding their animals). 


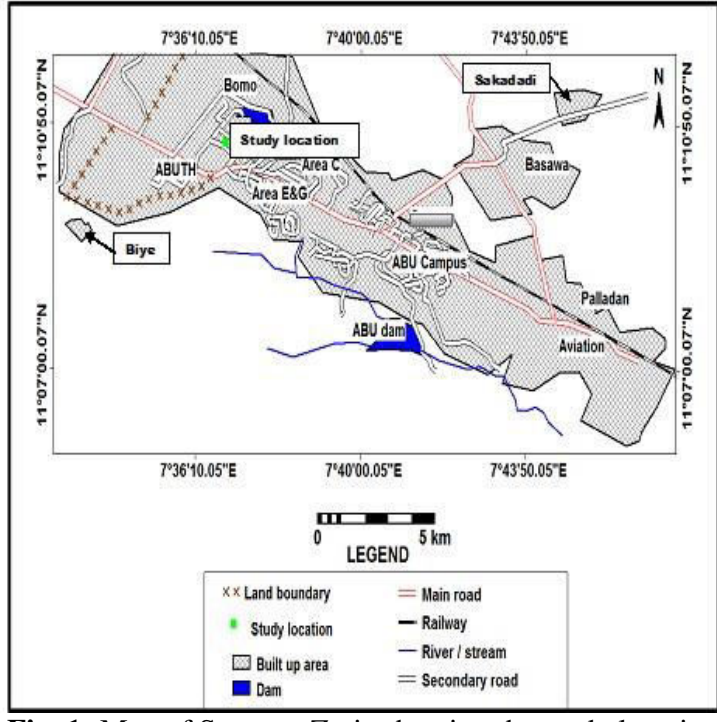

Fig. 1: Map of Samaru, Zaria showing the study location

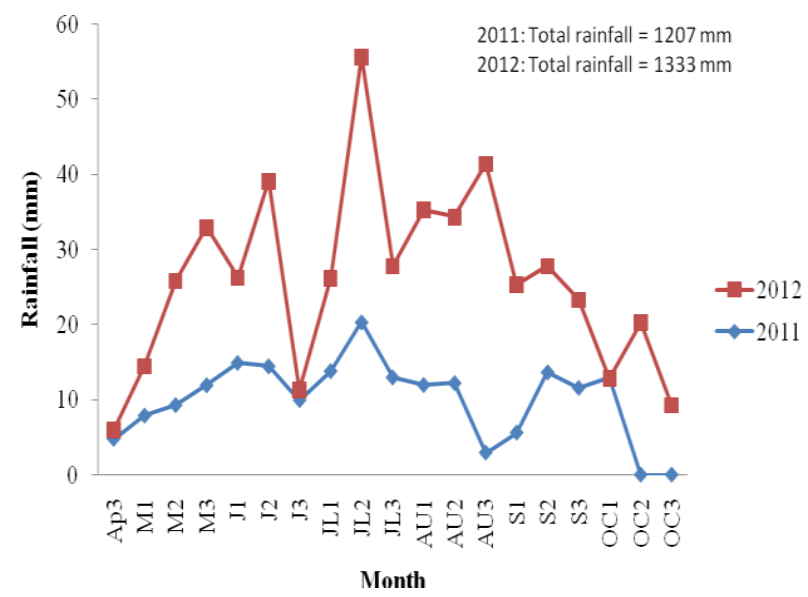

Fig. 2: Decadal rainfall patterns in Samaru during 2011 and 2012 cropping seasons

\section{Soybean Seed Inoculation and Planting}

The soybean seeds were inoculated with commercial rhizobium inoculants, manufactured and distributed by IITA business incubation platform, Legume inoculant at $400 \mathrm{~g} \mathrm{ha}^{-1}$ (inoculated soybean), while some seeds were not inoculated (uninoculated soybean). Before inoculation, the soybean seeds were sterilized, as outlined by Vincent (1970). Both maize and soybean seeds were sown on $1^{\text {st }}$ July 2011 and $16^{\text {th }}$ July 2012 respectively. The maize seeds were sown manually, two seeds per hole at an intra-line or intra-row spacing of $25 \mathrm{~cm}$. The seedlings were thinned to one plant per stand at two weeks after sowing to give a plant population of approximately 53,333 plants $\mathrm{ha}^{-1}$. Soybean seeds were drilled on the lines or ridges and covered lightly with soil. The uninoculated soybean treatment rows were sown first in order to avoid cross contamination. The seedlings were thinned to one plant per hill at a spacing of $5 \mathrm{~cm}$ to achieve a population of approximately 266,667 plants $\mathrm{ha}^{-1}$.

\section{Fertilizer Application}

Phosphorus fertilizer (single super phosphate; SSP) and potassium (Muriate of potash; MOP) were applied to all the plots planted to maize at the rate of $60 \mathrm{~kg} \mathrm{P}_{2} \mathrm{O}_{5} \mathrm{ha}^{-1}$ and $60 \mathrm{~kg} \mathrm{~K}_{2} \mathrm{O} \mathrm{ha}{ }^{-1}$, whereas those of soybean received $40 \mathrm{~kg} \mathrm{P}_{2} \mathrm{O}_{5} \mathrm{ha}^{-1}$ and 20 $\mathrm{kg} \mathrm{K}_{2} \mathrm{O} \mathrm{ha}^{-1}$ at planting in both seasons, respectively. The sub plots were divided into four; only maize plots in both cropping seasons received urea fertilizer application at the rates of $0 \mathrm{~kg} \mathrm{~N} \mathrm{ha}^{-1}$, $40 \mathrm{~kg} \mathrm{~N} \mathrm{ha}{ }^{-1}, 80 \mathrm{~kg} \mathrm{~N} \mathrm{ha}^{-1}$ and $120 \mathrm{~kg} \mathrm{~N} \mathrm{ha}^{-1}$ Nitrogen fertilizer rate was applied in two splits; first application (1/3) was done at four weeks after sowing, while the remaining part (2/3) was done as second application at eight weeks after sowing.

\section{Soil Sampling}

Initial soil samples were collected systematically by dividing the field into eight sections. A total of 16 points; two points per division within the field were sampled using the soil auger at $0-15 \mathrm{~cm}$ depth before trial establishment. The samples were bulked and thoroughly mixed and a composite sample was taken, processed and stored for analysis. At the end of the field experiments in 2012 , four disturbed surface soil samples $(0-15 \mathrm{~cm}$ depth) were taken at alternate points from four inner ridges per plot (96 soil samples) using a soil auger. The samples were bulked to form a composite sample per plot. The sub-samples taken were bagged and properly labelled. A part was airdried, crushed lightly and sieved through the $2 \mathrm{~mm}$ and $0.5 \mathrm{~mm}$ sieves in readiness for carbon and nitrogen analysis. Undisturbed soil samples were taken from the net plot, comprising two inner rows per plot using core sampler; these were used to determine the bulk density and soil depth.

\section{Laboratory Soil Analysis}

Initial and end of year (2011 and 2012) soil samples obtained at depths $0-15$ and $15-30 \mathrm{~cm}$ from the field, were air dried, sieved through $2 \mathrm{~mm}$ diameter sieve and subjected to laboratory analysis. Parameters evaluated in the laboratory of Department of Soil Science Ahmadu Bello University were: (i) soil particle size distribution by hydrometer method (Gee and Bauder (1986); (ii) soil bulk density using the core method (Grossman and Reinsch, 2002); (iii) soil pH electrometrically in $0.01 \mathrm{M}$ calcium chloride solution at soil-solution ratio of 1:2.5 and read on a $\mathrm{pH}$ meter (Hendershotet al., 1993); (iv) soil organic carbon by WalkleyBlack wet oxidation method (Nelson and Sommers, 1982); (v) available phosphorus by Bray 1 method (Olson and Sommers 1982); (vi) total nitrogen by the Kjeidahl digestion method (Bremner and Mulvaney 1982); and (vii) cation exchange capacity of the soil by the $1 \mathrm{~N} \mathrm{NH}_{4} \mathrm{OAc}$ method (Rhoades, 1987). 


\section{Statistical Analysis}

Data collected were subjected to analysis of variance (ANOVA) using the mixed linear model procedure of SAS Institute Inc. (2009). Effects of the various factors and their interactions were compared by computing least square means and standard errors of difference (SED) at $5 \%$ level of probability.

\section{RESULTS}

\section{Initial Soil Characterization}

The initial characteristics of soils at the experimental site are presented in Table 1. The data showed that sand fraction was higher in soil, followed by silt, while the lowest was clay. The values of bulk density $\left(1.41 \mathrm{Mg} \mathrm{m}^{-3}\right)$ and total porosity $(52.83 \%)$ were medium in the soil. The soil reaction was slightly acidic, with $\mathrm{pH}$ of 5.40 in $\mathrm{H}_{2} \mathrm{O}$ and 4.50 in $\mathrm{CaCl}_{2}$, while available $\mathrm{P}(9.14 \mathrm{mg}$ $\mathrm{kg}^{-1}$ ) was medium. The soil was characterized by low organic matter $\left(9.48 \mathrm{~g} \mathrm{~kg}^{-1}\right)$, total nitrogen $\left(0.46 \mathrm{~g} \mathrm{~kg}^{-1}\right)$ and carbon nitrogen ratio (12), as well as exchangeable cations and acidity, indicating that the soil was low in fertility.

\section{Soil Organic Carbon and Total Nitrogen}

Effect of tillage practices on soil organic carbon and total nitrogen are presented in Table 2. Soil organic carbon (OC) was not significantly different among the tillage systems. However, the initial value of $\mathrm{OC}$ of the soil was lower than that obtained under both tillage systems, with a difference of $14.91 \%$ for CT and $19.82 \%$ for RT. Values of soil total nitrogen (TN) were significantly lower in soil under CT plots, compared to that under RT plots with $4.72 \%$ difference. Results also show percentage increase of $141.30 \%$ under RT and $130.43 \%$ under CT considering the initial TN of the soils before the experiment.

Cropping system had a significant effect on soil organic carbon and total nitrogen (Table 2). The four cropping systems evaluated in this study revealed substantially greater OC contents than initial OC contents $\left(5.50 \mathrm{~g} \mathrm{~kg}^{-1}\right)$ obtained at the same $0-15 \mathrm{~cm}$ depth before the experiment. The same observations found in $\mathrm{OC}$ were obtained for TN. Soil under inoculated soybean-maize rotation had the highest OC and TN contents, which were significantly different from other cropping systems. Cropping systems with inoculated soybean rotation contributed the highest amounts of OC and TN in soil, followed by inoculated soybean intercropping with maize; the lowest amount was recorded for uninoculated soybean intercropping with maize, considering the initial TN in soil. However, total $\mathrm{N}$ in the plots previously cropped with inoculated soybean (rotation) or maize/inoculated soybean (intercrop) was 20 and $28 \%$ higher than those in rotation plots with uninoculated soybean, and intercrop with uninoculated soybean, respectively.
Table 1: Initial soil properties of the experimental site

\begin{tabular}{llc}
\hline Soil properties & Unit & Test value \\
\hline Bulk density & $\mathrm{Mg} \mathrm{m}^{-3}$ & 1.41 \\
Moisture content & $\mathrm{g} \mathrm{kg}^{-1}$ & 229.55 \\
Total porosity & $\%$ & 52.83 \\
Sand & $\mathrm{g} \mathrm{kg}^{-1}$ & 671.20 \\
$\mathrm{Silt}$ & $\mathrm{g} \mathrm{kg}^{-1}$ & 230.00 \\
Clay & $\mathrm{g} \mathrm{kg}^{-1}$ & 98.80 \\
Texturalclass & & Sandy loam \\
pH in $\mathrm{H}_{2} \mathrm{O}$ & & 5.40 \\
$\mathrm{pH}\left(\mathrm{CaCl}_{2}\right)$ & & 4.50 \\
Total nitrogen & $\mathrm{g} \mathrm{kg}^{-1}$ & 0.46 \\
Organic matter & $\mathrm{g} \mathrm{kg}^{-1}$ & 9.48 \\
Carbon nitrogen ratio & & 12 \\
Phosphorus & $\mathrm{mg} \mathrm{kg}^{-1}$ & 9.14 \\
Exchangeable cations & $\mathrm{cmol} \mathrm{kg}^{-1}$ & \\
Calcium & $"$ & 2.32 \\
Magnesium & $"$ & 0.40 \\
Potassium & $"$ & 0.25 \\
Sodium & $"$ & 0.10 \\
Exchangeable acidity & $\mathrm{cmol} \mathrm{kg}^{-1}$ & 1.08 \\
\hline
\end{tabular}

Effect of nitrogen fertilizer application on soil OC and TN content in soil are presented in Table 2. Organic carbon and total $\mathrm{N}$ in soil were significantly affected by $\mathrm{N}$ fertilizer rates at $5 \%$ level of probability. The values were higher in soil with $120 \mathrm{~kg} \mathrm{~N} \mathrm{ha}^{-1}$, followed by $80 \mathrm{~kg} \mathrm{~N} \mathrm{ha}^{-1}$. The least were obtained for plots without $\mathrm{N}$ fertilizer application $\left(0 \mathrm{~kg} \mathrm{~N} \mathrm{ha}^{-1}\right)$ which increased with increase in $\mathrm{N}$ fertilizer application rate (Table 2).

\section{Soil Carbon to Nitrogen Ratio (C/N ratio)}

The data in Table 2 also show no significant difference between the tillage systems on $\mathrm{C} / \mathrm{N}$ ratio in the soil studied. The value was lower in soil under RT than CT with $0.34 \%$. Generally, the soil $\mathrm{C} / \mathrm{N}$ ratios under the two tillage systems were lower than the values obtained before the study.

The soil $\mathrm{C} / \mathrm{N}$ ratios obtained under the various cropping systems ranged from 5.40 to 6.56 , with a mean of 6.01 (Table 2). The $\mathrm{C} / \mathrm{N}$ ratios in soil under cropping systems were significantly different $(p<0.05)$. The ratios were also generally low, with the highest values under both inoculated and uninoculated soybean-maize intercropping system. However, there was significant difference in the results for inoculated and uninoculated soybeanmaize rotation. Similar trend occurred for inoculated and uninoculated soybean-maize intercropping system. There was also a significant difference in the results for $\mathrm{N}$ fertilizer application rates on $\mathrm{C} / \mathrm{N}$ ratio (Table 2 ). The values were generally low, the highest value being for soil treated with $120 \mathrm{~kg} \mathrm{~N}$ $\mathrm{ha}^{-1}$, which was significantly at par with that for 40 $\mathrm{kg} \mathrm{N} \mathrm{ha}{ }^{-1}$. The values ranged from 5.15 to 6.59 , with a mean of 5.93. Generally, the value obtained at $0 \mathrm{~kg} \mathrm{~N} \mathrm{ha}{ }^{-1}$ treatment was significantly lower than those of other $\mathrm{N}$ treatment plots, having percent differences of $17.08 \%$ for $40 \mathrm{~kg} \mathrm{~N} \mathrm{ha}^{-1}, 15.92 \%$ for $80 \mathrm{~kg} \mathrm{~N} \mathrm{ha}^{-1}$ and $27.96 \%$ for $120 \mathrm{~kg} \mathrm{~N} \mathrm{ha}^{-1}$. 
Table 2: Selected chemical properties of soil productivity indicators

\begin{tabular}{|c|c|c|c|c|c|}
\hline Treatment & $\begin{array}{c}\mathrm{OC} \\
(\mathrm{g} / \mathrm{kg})\end{array}$ & $\begin{array}{c}\mathrm{TN} \\
(\mathrm{g} / \mathrm{kg})\end{array}$ & $\begin{array}{l}\mathrm{C} / \mathrm{N} \\
\text { Ratio }\end{array}$ & $\begin{array}{c}\mathrm{pH} \\
\mathrm{CaCl}_{2}\end{array}$ & $\begin{array}{c}\text { Ava. P } \\
(\mathrm{mg} / \mathrm{kg})\end{array}$ \\
\hline \multicolumn{6}{|c|}{ Tillage (TS) } \\
\hline Conventional tillage & $6.32 \mathrm{a}$ & $1.06 \mathrm{a}$ & $5.96 \mathrm{a}$ & $4.43 b$ & $8.41 \mathrm{~b}$ \\
\hline Reduced tillage & $6.59 \mathrm{a}$ & $1.11 \mathrm{a}$ & $5.94 \mathrm{a}$ & $5.05 \mathrm{a}$ & $9.95 \mathrm{a}$ \\
\hline SE & 0.03 & 0.20 & 0.20 & 0.04 & 0.16 \\
\hline \multicolumn{6}{|c|}{ Cropping system (CS) } \\
\hline Rotation inoculated & $8.05 \mathrm{a}$ & $1.49 \mathrm{a}$ & $5.40 \mathrm{~b}$ & 5.03 & $9.95 \mathrm{a}$ \\
\hline Rotation uninoculated & $5.84 \mathrm{c}$ & $0.99 \mathrm{c}$ & $5.90 \mathrm{~b}$ & 4.99 & $9.45 \mathrm{ab}$ \\
\hline Intercrop inoculated & $6.75 b$ & $1.09 \mathrm{~b}$ & $6.19 \mathrm{a}$ & 5.02 & $9.18 \mathrm{~b}$ \\
\hline Intercrop uninoculated & $5.18 \mathrm{c}$ & $0.78 \mathrm{~d}$ & $6.56 \mathrm{a}$ & 4.92 & $9.14 \mathrm{~b}$ \\
\hline SE & 0.30 & 0.02 & 0.14 & 0.06 & 0.22 \\
\hline \multicolumn{6}{|c|}{ N Rate $\left(\mathrm{kg} \mathrm{ha}^{-1}\right)$} \\
\hline 0 & $5.36 \mathrm{c}$ & $1.04 \mathrm{~b}$ & $5.15 \mathrm{c}$ & 5.06 & $8.62 \mathrm{a}$ \\
\hline 40 & $6.39 \mathrm{~b}$ & $1.06 \mathrm{~b}$ & $6.03 \mathrm{ab}$ & 4.98 & $8.59 \mathrm{a}$ \\
\hline 80 & $6.57 \mathrm{~b}$ & $1.10 \mathrm{ab}$ & $5.97 \mathrm{~b}$ & 4.96 & $8.65 \mathrm{a}$ \\
\hline 120 & $7.51 \mathrm{a}$ & $1.14 \mathrm{a}$ & $6.59 \mathrm{a}$ & 4.55 & $8.16 \mathrm{a}$ \\
\hline SE & 0.27 & 0.01 & 0.11 & 0.03 & 0.42 \\
\hline \multicolumn{6}{|c|}{ Interaction } \\
\hline TS*CS & $*$ & $*$ & $*$ & NS & $*$ \\
\hline $\mathrm{TS} * \mathrm{~N}$ rate & NS & NS & NS & NS & $*$ \\
\hline $\mathrm{CS} * \mathrm{~N}$ rate & $*$ & $*$ & NS & NS & NS \\
\hline $\mathrm{TS} * \mathrm{CS} * \mathrm{~N}$ rate & NS & NS & NS & NS & NS \\
\hline
\end{tabular}

Tillage and Cropping System Interaction on Total Nitrogen and $\mathrm{C} / \mathrm{N}$ Ratio

Significant interaction between tillage and cropping systems was only observed for TN (Fig. 3) and C/N ratio (Fig. 4). The $\mathrm{TN}$ content of the soil found under RT was higher than that under CT in all the cropping system combinations. The reverse was the case for $\mathrm{C} / \mathrm{N}$ ratio. The result also revealed that both tillage practices had higher soil total $\mathrm{N}$ contents under inoculated soybean-maize rotation combination than other cropping systems. Reduced tillage with inoculated soybean-maize rotation and uninoculated soybean-maize rotation recorded lower $\mathrm{C} / \mathrm{N}$ ratio and higher $\mathrm{C} / \mathrm{N}$ ratio under inoculated soybean-maize intercropping and inoculated soybean-maize intercropping, respectively, than those of CT combinations.

\section{Soil Reaction}

Data on the effects of tillage on soil reaction, presented in Table 2, show a significant difference between the various values, with RT having higher values than those of $\mathrm{CT}$ for both water and $\mathrm{CaCl}_{2}$ solution. The percent differences were $2.10 \%$ for water and $2.38 \%$ for $\mathrm{CaCl}_{2}$ solution. The $\mathrm{pH}$ under CT was lower, while that of RT was higher than the initial soil $\mathrm{pH}$ of 4.50 in $\mathrm{CaCl}_{2}$, with percent differences of $1.58 \%$ for $\mathrm{CT}$ and $-10.89 \%$ for RT.

However, the soil $\mathrm{pH}$ values for the cropping systems did not significantly differ (Table 2); the highest values were obtained for soil under inoculated soybean-maize rotation, followed by that in inoculated soybean-maize intercropping system. The lowest values were recorded for uninoculated soybean-maize intercrop. The variation of soil $\mathrm{pH}$ among the cropping systems could be said to reflect the levels of soil nutrient losses through plant uptake, as well as those gained through plant residues.
Moreover, there were no significant differences in soil $\mathrm{pH}$ due to $\mathrm{N}$ fertilizer rates (Table 2). The result indicated that as $\mathrm{N}$ fertilizer rate increases, soil $\mathrm{pH}$ decreases gradually, in the order of $0>40$ $>80>120 \mathrm{~kg} \mathrm{~N} \mathrm{ha}^{-1}$. Generally, the range of values was 6.15-6.07 (water) and 5.06-4.55 $\left(\mathrm{CaCl}_{2}\right)$, with the means of 6.12 and 4.89 respectively.

\section{Available Soil Phosphorus}

The result on the effects of soil tillage systems on available soil phosphorus is presented in Table 2 . The data showed that tillage had no significant effect on available soil $\mathrm{P}$. The values were slightly higher for soil under RT than that for CT, with $4.71 \%$ difference. The values were generally low; in fact, lower than the initial value of $9.48 \mathrm{mg} \mathrm{kg}^{-1}$.

The data on available soil $\mathrm{P}$ obtained for cropping systems is also in Table 2. The data showed that cropping systems significantly $(p<$ 0.05 ) influenced available soil $P$. The value of available $\mathrm{P}$ was highest for soil under rhizobium inoculated soybean-maize rotation $\left(8.95 \mathrm{mg} \mathrm{kg}^{-1}\right)$, followed by uninoculated soybean-maize rotation $\left(8.45 \mathrm{mg} \mathrm{kg}^{-1}\right)$. The least value was in uninoculated soybean/maize intercrop $\left(8.14 \mathrm{mg} \mathrm{kg}^{-1}\right)$. The values were generally lower than the initial value $(9.48 \mathrm{mg}$ $\mathrm{kg}^{-1}$ ), with percentage differences of $5.92 \%$ for inoculated soybean-maize rotation, $12.19 \%$ for uninoculated soybean-maize rotation, $15.89 \%$ for inoculated soybean/maize intercrop and $16.46 \%$ for uninoculated soybean/maize intercrop.

The data in Table 2 also show that there was no significant difference in the effects of $\mathrm{N}$ fertilizer rate on available soil $\mathrm{P}$. But available phosphorus was higher in plots treated with no $\mathrm{N}$ fertilizer rate than in other $\mathrm{N}$ treatment plots. The results reveal that the soil $\mathrm{P}$ content decreased with increasing $\mathrm{N}$ fertilizer application rates. 


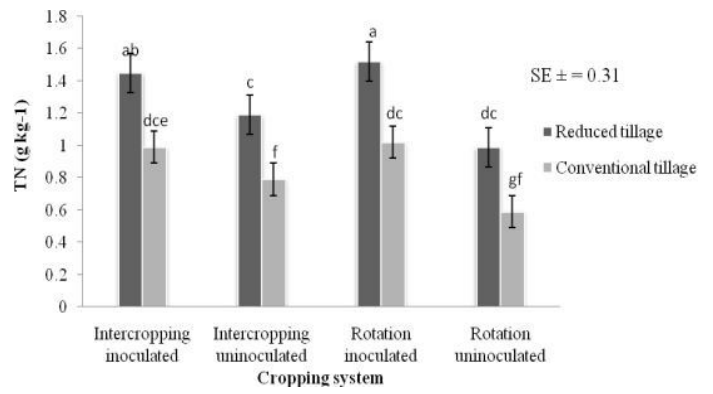

Fig. 3: Tillage and cropping systems interaction on soil TN

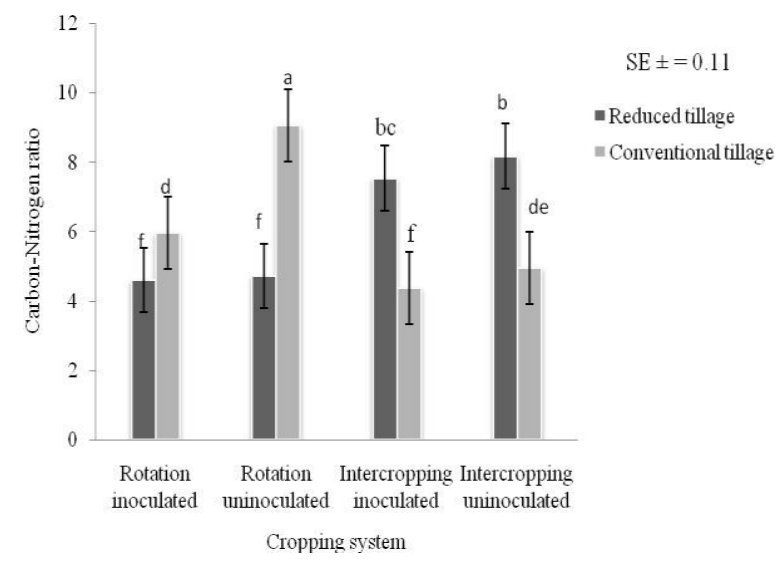

Fig. 4: Tillage and cropping systems interaction on carbon-nitrogen ratio in soil

\section{Effects of Tillage and Cropping Systems on Soil Available Phosphorus \\ Tillage and cropping systems showed a significant effect on the P content of soil (Fig. 5), with a greater value in RT with rhizobium inoculated soybean- maize rotation than those of other treatments. Available P content in the soil was higher in CT plots than in RT plots previously cropped to uninoculated soybean; but the reverse was the case for inoculated and uninoculated soybean/maize intercropped under the two tillage systems.}

\section{Exchangeable Bases and Acidity of the Soil}

Results for exchangeable bases ( $\mathrm{Ca}, \mathrm{Mg}, \mathrm{K}$ and $\mathrm{Na}$ ) and acidity (EA) in the soil under tillage systems in 2012 are shown (Table 3). Tillage had no significant $(p<0.05)$ influence on exchangeable bases and EA, except exchangeable $\mathrm{Ca}$. Conventional tillage (CT) had higher value of soil exchangeable $\mathrm{Ca}$ compared with reduced tillage (RT) treatment plots, with a percentage difference of $12.5 \%$.

Effect of cropping systems on soil exchangeable bases and acidity (Table 3 ) showed significant $(p<0.05)$ difference in values for cropping systems on $\mathrm{Ca}$ among other soil exchangeable bases and EA. Rhizobium inoculated soybean-maize rotation plots had higher values of exchangeable bases $\mathrm{Ca}$ than other cropping systems. Generally, the values of exchangeable bases and EA were low.
The results of soil exchangeable bases and acidity analyses as influenced by the four levels of Nitrogen fertilizer treatments are shown in Table 3. No significant differences in exchangeable bases and exchangeable acidity were found among plots treated with the four nitrogen levels $(0 \mathrm{~kg} \mathrm{~N}$ $\mathrm{ha}^{-1}, 40 \mathrm{~kg} \mathrm{~N} \mathrm{ha}^{-1}, 80 \mathrm{~kg} \mathrm{~N} \mathrm{ha}^{-1}$ and $120 \mathrm{~kg} \mathrm{~N} \mathrm{ha}^{-1}$ ) at probability level of $5 \%$.

\section{Cation Exchange Capacity and Base Saturation} of the Soil as Influenced by Treatments

The CEC and percentage base saturation (\%BSat) of the soil were significantly $(p<0.05)$ affected by tillage practices, but soil ECEC was not (Table 3). The result shows that CT had lower values of CEC, ECEC and BSat content of the soil, compared with what obtained at the RT treatment plots. The percentage differences were $6.93 \%$ for CEC, $1.06 \%$ for ECEC and $4.17 \%$ for BSat.

Table 3 also contains data on the effects of various cropping systems on soil CEC, ECEC and $\%$ BSat. The soil CEC and ECEC were significantly $(p<0.05)$ affected by cropping systems; \%BSat was not. Rhizobium inoculated soybean-maize rotation plots had the highest values of CEC, ECEC and \%BSat in the soil among the cropping systems. However, these values were consistently higher in soil under inoculated soybean-maize rotation than those in uninoculated soybean-maize rotation, with the percentage differences of $22.92 \%$ for CEC, $18.06 \%$ for ECEC and $4.29 \%$ for \%BSat. A similar trend was found for inoculated soybean-maize intercrop and uninoculated soybean-maize intercrop, with percentage differences of $15.72 \%$ for CEC, $5.41 \%$ for ECEC and $5.97 \%$ for \%BSat.

The data on the effect of $\mathrm{N}$ fertilizer rate on soil CEC, ECEC and \%BSat (Table 3) also show no differences among $\mathrm{N}$ fertilizer treatments, except on BSat. Plots that received 0 and $40 \mathrm{~kg} \mathrm{~N}$ $\mathrm{ha}^{-1}$ maintained the same value of CEC compared to other $\mathrm{N}$ rates; higher value was recorded in soil under $80 \mathrm{~kg} \mathrm{~N}^{-1}{ }^{-1} \mathrm{~N}$ which was at par with $40 \mathrm{~kg}$ $\mathrm{N} \mathrm{ha}^{-1} \mathrm{~N}$ fertilizer treated plots. The same trend was found for ECEC. The CEC and ECEC of the soil were at their peak when $80 \mathrm{~kg} \mathrm{~N}^{-1}$ was applied, indicating that additional increase caused a decrease.

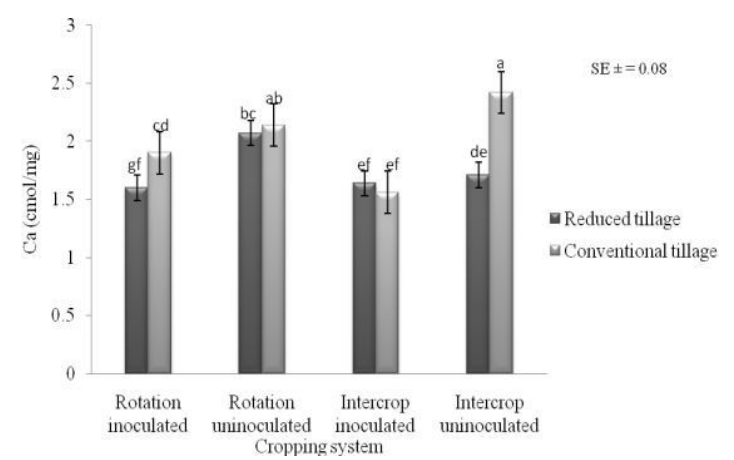

Fig. 5: Tillage and cropping systems interaction effect on available phosphorus 
Table 3: Exchangeable bases and acidity of soil productivity indicators

\begin{tabular}{|c|c|c|c|c|c|c|c|c|}
\hline \multirow[t]{2}{*}{ Treatment } & $\mathrm{Ca}$ & $\mathrm{Mg}$ & $\mathrm{K}$ & $\mathrm{Na}$ & CEC & EA & ECEC & \multirow{2}{*}{$\begin{array}{c}\text { B.Sat } \\
(\%)\end{array}$} \\
\hline & \multicolumn{7}{|c|}{$(\mathrm{cmol} / \mathrm{mg})$} & \\
\hline \multicolumn{9}{|c|}{ Tillage practices (TP) } \\
\hline Conventional tillage & $2.00 \mathrm{a}$ & $0.56 \mathrm{a}$ & $0.10 \mathrm{a}$ & $0.08 \mathrm{a}$ & $2.55 \mathrm{~b}$ & $1.18 \mathrm{a}$ & $3.73 \mathrm{a}$ & $69 b$ \\
\hline Reduced tillage & $1.75 b$ & $0.60 \mathrm{a}$ & $0.13 \mathrm{a}$ & $0.07 \mathrm{a}$ & $2.74 a$ & $1.03 \mathrm{~b}$ & $3.77 \mathrm{a}$ & $72 \mathrm{a}$ \\
\hline SE & 0.06 & 0.03 & 0.01 & 0.01 & 0.06 & 0.04 & 0.08 & 0.77 \\
\hline \multicolumn{9}{|c|}{ Cropping systems (CS) } \\
\hline Rotation inoculated & $2.24 \mathrm{a}$ & $0.64 \mathrm{a}$ & $0.14 \mathrm{a}$ & $0.06 \mathrm{a}$ & $3.11 \mathrm{a}$ & $1.06 \mathrm{a}$ & $4.25 \mathrm{a}$ & $73 a$ \\
\hline Rotation uninoculated & $1.92 \mathrm{~b}$ & $0.55 \mathrm{a}$ & $0.10 \mathrm{a}$ & $0.07 \mathrm{a}$ & $2.53 \mathrm{bc}$ & $1.08 \mathrm{a}$ & $3.60 \mathrm{~b}$ & $70 \mathrm{a}$ \\
\hline Intercrop inoculated & $1.77 \mathrm{bc}$ & $0.60 \mathrm{a}$ & $0.11 \mathrm{a}$ & $0.07 \mathrm{a}$ & $2.65 b$ & $1.17 \mathrm{a}$ & $3.74 b$ & $71 \mathrm{a}$ \\
\hline Intercrop uninoculated & $1.58 \mathrm{c}$ & $0.54 \mathrm{a}$ & $0.10 \mathrm{a}$ & $0.08 \mathrm{a}$ & $2.29 \mathrm{c}$ & $1.11 \mathrm{a}$ & $3.46 \mathrm{~b}$ & $67 \mathrm{a}$ \\
\hline SE & 0.09 & 0.05 & 0.02 & 0.01 & 0.09 & 0.05 & 0.11 & 1.09 \\
\hline \multicolumn{9}{|c|}{$\mathrm{N}$ rates $\left(\mathrm{kg} \mathrm{ha}^{-1}\right)$} \\
\hline 0 & $1.86 \mathrm{a}$ & $0.53 \mathrm{a}$ & $0.12 \mathrm{a}$ & $0.07 \mathrm{a}$ & $2.58 \mathrm{a}$ & $1.01 \mathrm{~b}$ & $3.59 \mathrm{a}$ & $72 \mathrm{a}$ \\
\hline 40 & $1.78 \mathrm{a}$ & $0.61 \mathrm{a}$ & $0.12 \mathrm{a}$ & $0.07 \mathrm{a}$ & $2.58 \mathrm{a}$ & $1.05 \mathrm{~b}$ & $3.63 \mathrm{a}$ & $71 \mathrm{a}$ \\
\hline 80 & $1.97 \mathrm{a}$ & $0.59 a$ & $0.11 \mathrm{a}$ & $0.08 \mathrm{a}$ & $2.78 \mathrm{a}$ & $1.15 \mathrm{ab}$ & $3.93 a$ & $71 \mathrm{a}$ \\
\hline 120 & $1.88 \mathrm{a}$ & $0.61 \mathrm{a}$ & $0.10 \mathrm{a}$ & $0.08 \mathrm{a}$ & $2.67 \mathrm{a}$ & $1.21 \mathrm{a}$ & $3.88 \mathrm{a}$ & $69 b$ \\
\hline SE & 0.18 & 0.02 & 0.01 & 0.01 & 0.07 & 0.02 & 0.04 & 0.38 \\
\hline \multicolumn{9}{|c|}{ Interaction } \\
\hline $\mathrm{TP} * \mathrm{CS}$ & $*$ & $*$ & NS & NS & NS & $*$ & NS & $*$ \\
\hline $\mathrm{TP} * \mathrm{~N}$ rate & * & $*$ & NS & NS & $*$ & NS & NS & * \\
\hline $\mathrm{CS} * \mathrm{~N}$ rate & $*$ & NS & NS & NS & NS & $*$ & NS & $*$ \\
\hline $\mathrm{TS} * \mathrm{CS} * \mathrm{~N}$ rate & NS & NS & NS & NS & NS & $*$ & NS & NS \\
\hline
\end{tabular}

CEC - cation exchange capacity, EA - exchangeable acidity, ECEC - effective cation exchange capacity, \%BSat - Percent base saturation, NS - not significant at $p<0.05$, *significant at $p<0.05$

Tillage, Cropping System and $\mathbf{N}$ Fertilizer Interaction on Some Soil Cation Exchange Indices A significant interaction was found between tillage practices and cropping systems on $\mathrm{Ca}, \mathrm{Mg}$, and $\mathrm{EA}$, as well as on \%BSat (Figs. 6, 7, 8 and 9, respectively). The highest value of $\mathrm{Ca}$ occurred under $\mathrm{CT}$ with maize-soybean uninoculated intercrop, followed by maize-soybean uninoculated. The lowest value was in RT with maize-soybean inoculated rotation. The reverse was true for $\mathrm{Mg}$ and \%BSat. The interactions between $\mathrm{N}$ rates and tillage practices on $\mathrm{Ca}$ (Fig. 10), Mg (Fig. 11), CEC (Fig. 12) and percentage BSat (Fig. 13) differed significantly $(p<0.05)$. The same trend was observed for $\mathrm{N}$ rates and cropping systems on Ca (Fig. 14), EA (Fig. 15) and \%BSat (Fig. 16). Thus tillage and cropping systems with $\mathrm{N}$ fertilizer influenced availability of nutrients in soil, as well as plant use of such nutrients than when any of these treatments is used solely. However, their values were partly higher in inoculated rotation at all levels $\mathrm{N}$ fertilizer application and they increased with $\mathrm{N}$ rate, except in $\mathrm{CEC}$ and $\mathrm{B}$. Sat. which shows a initial increase to the peak at $80 \mathrm{~kg} \mathrm{~N}^{-1}$ and then subsequent decrease with increase in $\mathrm{N}$ fertilizer application rate.

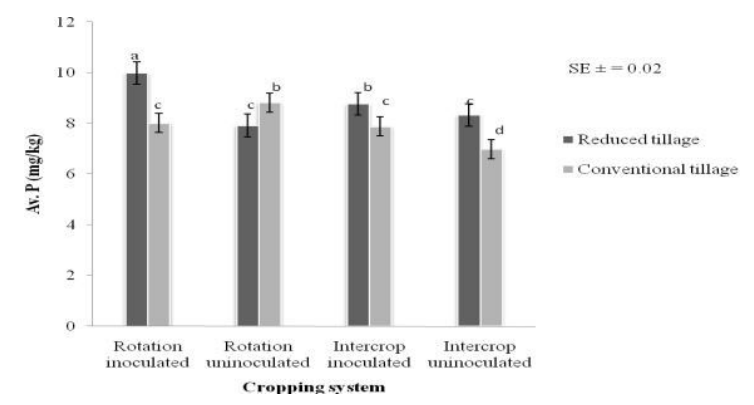

Fig. 6: Interaction between tillage and cropping system on exchangeable calcium $(\mathrm{Ca})$ in soil

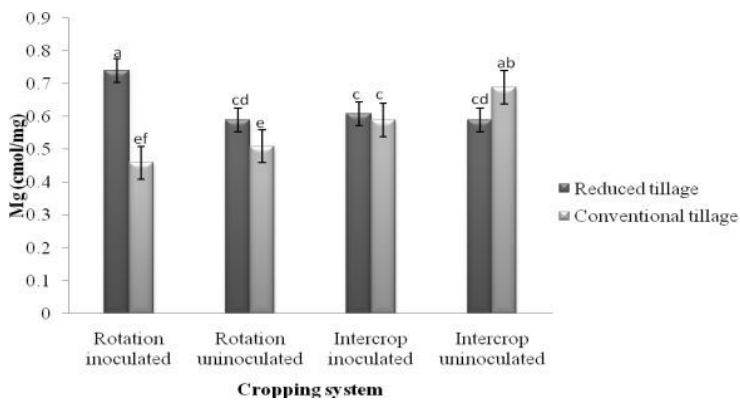

Fig. 7: Interaction between tillage and cropping system on exchangeable magnesium $(\mathrm{Mg})$ in soil

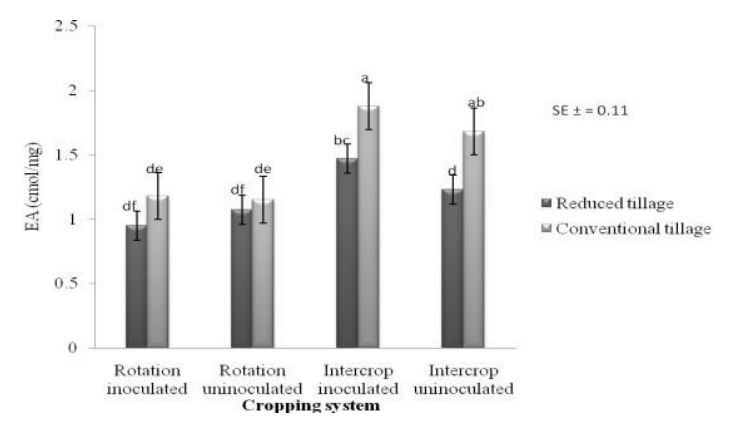

Fig. 8: Interaction between tillage and cropping system on exchangeable acidity (EA) in soil

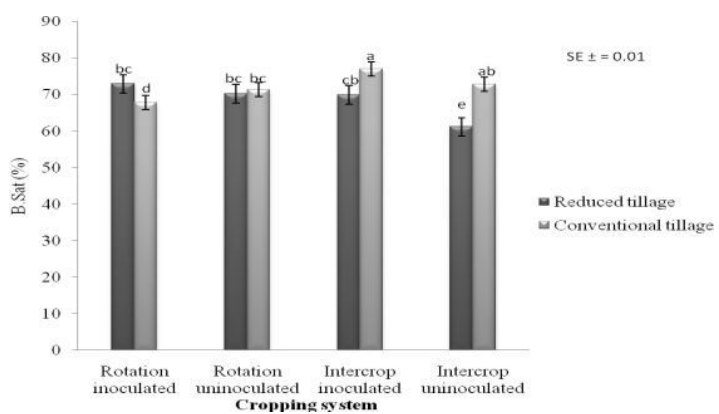

Fig. 9: Interaction between tillage and cropping system on percent base saturation (\% B. Sat.) in soil 


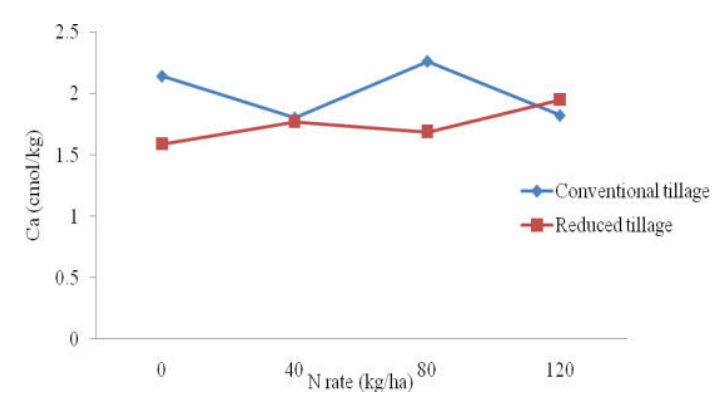

Fig. 10: Interaction effect between tillage and $\mathrm{N}$ rate on exchangeable calcium $(\mathrm{Ca})$ in soil

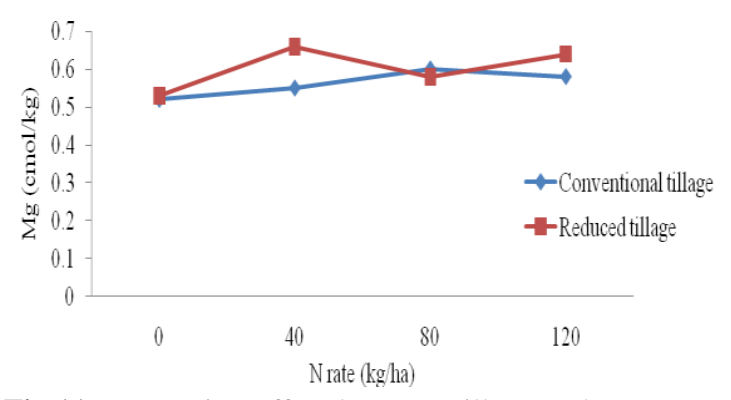

Fig.11: Interaction effect between tillage and $\mathrm{N}$ rate on exchangeable magnesium $(\mathrm{Mg})$ in soil

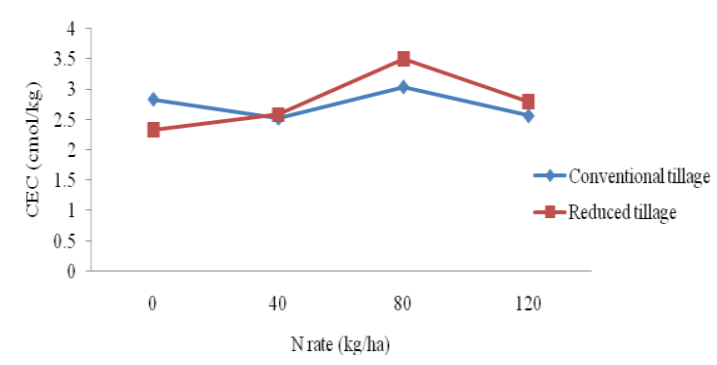

Fig.12: Interaction between tillage and $\mathrm{N}$ rate on cation exchangeable capacity (CEC) in soil

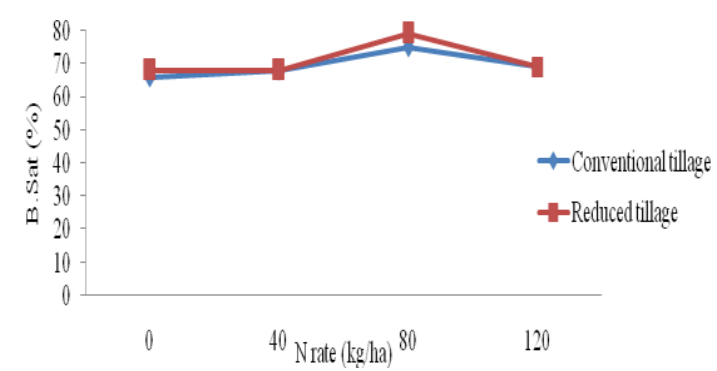

Fig. 13: Interaction between tillage and $\mathrm{N}$ rate on percent base saturation (\%BSat) in soil

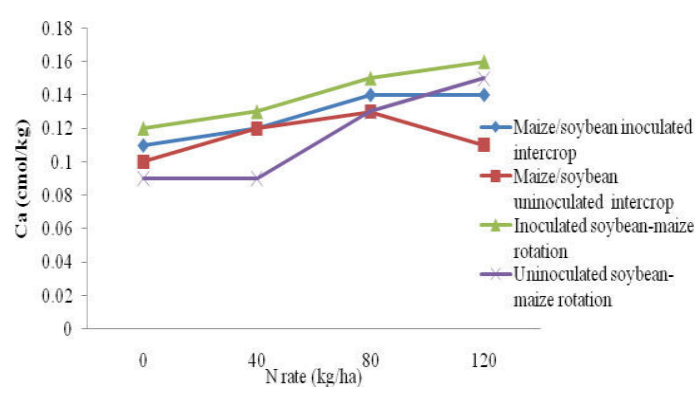

Fig. 14: Interaction between cropping systems and $\mathrm{N}$ rate on exchangeable calcium $(\mathrm{Ca})$ in soil

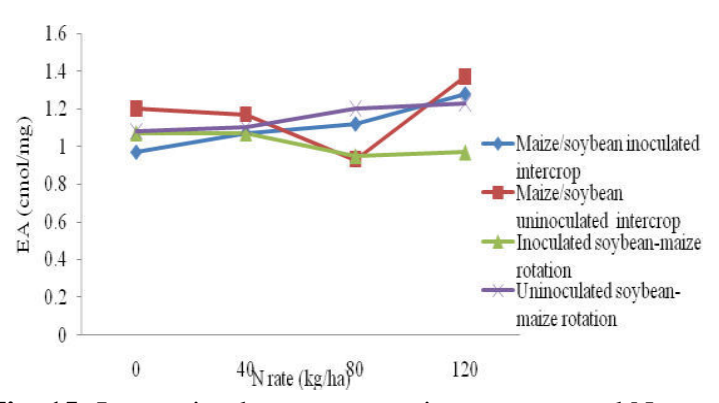

Fig. 15: Interaction between cropping systems and $\mathrm{N}$ rate on exchangeable acidity (EA) in soil

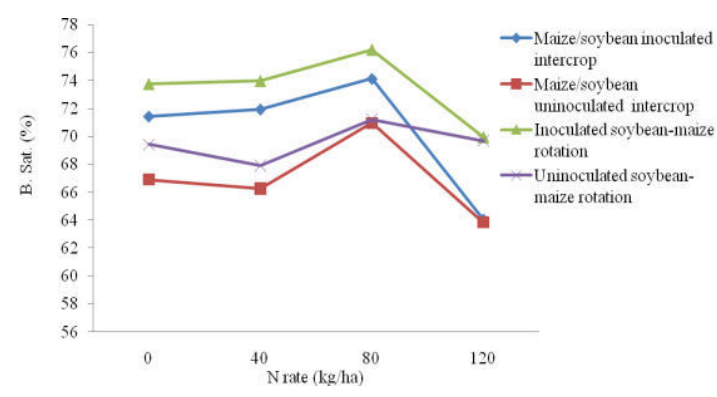

Fig. 16: Interaction between cropping systems and $\mathrm{N}$ rate on percent base saturation (\%BSat) in soil

\section{DISCUSSION}

Initial Soil Characterization

The results showed that the soil textural class was sandy loam with $9.9 \%$ clay. The value of bulk density was slightly above $1.39 \mathrm{Mg} \mathrm{m}^{-3}$ reported for surface soil of the same Northern Guinea savanna (Oikeh et al., 1998). The slightly acidic nature of the soil, low TN and OC reflected the true characteristic of a savanna Alfisol, which was due to uptake of basic cation by plant through cultivation and, partly, to the overall removal of crop residues by farmer after harvest. The available $\mathrm{P}$ in the study soil was medium, which falls below the critical level of 10 to $15 \mathrm{mg} \mathrm{kg}^{-1}$ according to the ratings of Esu (1991) and NSPFS (2005). The northern Guinea savanna of Nigeria is characterized by intensive cultivation, coupled with low input use and low capital base, resulting in reduced soil fertility and productivity. Extensive leaching and uptake of basic cation without replacement, rapid decomposition of organic matter due to high temperature, short fallow periods characterized by intensive cultivation and low input use and low capital base are largely responsible for low fertility status of Nigerian Savanna Alfisol (Oyinlola and Chude, 2010; Omeke et al., 2016).

\section{Soil Organic Carbon and Total Nitrogen in Soil} The significantly higher value of organic carbon (OC) and total nitrogen (TN) in soil found in RT could be attributed to high decomposition rate of plant residues due to much disturbance, less ground cover and mixing ability that conventional tillage has over reduced tillage. It may also be attributed to the reduced mineralization rate of soil organic 
matter due to less soil disturbance and greater protection of OC fractions within soil aggregate in reduced tillage (Al-Kaisi et al., 2005). The effects of conventional tillage practices on $\mathrm{OC}$ and $\mathrm{TN}$ dynamics depend, in part, on soil properties and environmental factors, such as soil texture, clay mineralogy, topography, and climate (Campbell et al., 1999). These environmental factors may have contributed to the significant difference observed in soil total $\mathrm{N}$ contents in response to tillage systems at $0-15 \mathrm{~cm}$ depth. However, greater total $\mathrm{N}$ and $\mathrm{OC}$ contents in soil under RT may have accrued from more ground cover and slow decomposition rate due to settlement of crop residues on the soil surface and the decreased contact of crop residues with soil microorganisms (Omeke et al., 2016). This implies that RT enhances redistribution of OC closer to the soil surface than CT.

Significantly higher OC and TN content in soil found under rhizobium inoculated soybean-maize rotation and intercrop could be due to high maizesoybean biomass production with low $\mathrm{C} / \mathrm{N}$ ratio, compared to sole maize. Similar observation was reported by Adebayo (2011) who studied cereal/legume rotation in a Guinea savanna Alfisol of Nigeria. Other factors that contributed to increase OC content in the cropping system are crop residues accruing from nodule mass, root and in-season fall-off leaves, as well as leftover shoot system after harvest (Omeke et al., 2016). This was supported by additional $\mathrm{N}$ fixed (residual effect of rotation) due to effectiveness of strain rhizobium used and possibly enhanced by low nitrogen content of the soil. The increases in $\mathrm{N}$ supply in previous soybean treatments and yield of subsequent maize was probably due to additional $\mathrm{N}$ fixed and left in the soil for the subsequent maize crop. Study conducted by Yusuf et al. (2006) showed that cowpea fixed 16-34 kg N ha-1 and soybean fixed between $41-50 \mathrm{~kg} \mathrm{~N} \mathrm{ha}^{-1}$ in the same Nigeria savanna Alfisol. Sanginga et al. (2002) reported that nodulating soybean improve soil total $\mathrm{N}$ with an estimated net $\mathrm{N}$ balance input from fixation following grain harvest of $43 \mathrm{~kg} \mathrm{~N} \mathrm{ha}^{-1}$. This would be more enhanced under inoculated soybean cropping systems, suggesting higher soil productivity improvement, compared to cropping systems without inoculated soybean.

The results also show that soil OC and $\mathrm{TN}$ increased with corresponding $\mathrm{N}$ fertilizer rate, and were significantly higher in plots that received 120 $\mathrm{kg} \mathrm{N} \mathrm{ha}{ }^{-1}$ than other $\mathrm{N}$ treatments which was statistically at par with $80 \mathrm{~kg} \mathrm{~N} \mathrm{ha}{ }^{-1}$. The implication is that $\mathrm{N}$ fertilizer application improves $\mathrm{OC}$ and $\mathrm{N}$ status of the soil due to better performance of the crops. This can partly be explained by the changes in composition of $\mathrm{OC}$; suggesting that addition of inorganic $\mathrm{N}$ reversed immobilization of mineral $\mathrm{N}$ by microorganisms (Karborzova-Saljnikov, 2004) due to a reduction in
$\mathrm{C} / \mathrm{N}$ ratio. The lower $\mathrm{C} / \mathrm{N}$ ratio in soil due to $\mathrm{N}$ treatments reflected the increase in microbial activity due to $\mathrm{N}$ fertilizer, which invariably enhanced decomposition and mineralization and, thereby, narrowed the $\mathrm{C} / \mathrm{N}$ ratio. Similarly, this was supported by the presence of inoculated soybean in the cropping systems, which enhanced stable soil environment. This stable environment can contribute to increasing soil $\mathrm{C}$ sequestration in the legumecereal cropping systems (Al-Kaisi et al., 2005). Thus, a low $\mathrm{C} / \mathrm{N}$ ratio suggests the release of soil $\mathrm{N}$ in form available to plants due to high microbial activity; the reverse is the case for high $\mathrm{C} / \mathrm{N}$ ratio.

\section{Effect of Tillage and Cropping Systems Interaction on $\mathbf{T N}$ and $\mathrm{C} / \mathrm{N}$ Ratio}

The significant interaction observed between tillage and cropping systems on $\mathrm{TN}$ and $\mathrm{C} / \mathrm{N}$ ratio implies that agronomic practices like integration of soybean inoculated or uninoculated in the maizebased cropping system under tillage system influences $\mathrm{N}$ status of the soil. Both tillage systems had higher soil total $\mathrm{N}$ under inoculated soybeanmaize rotation than other cropping systems with tillage combination, which were also lower in CT than RT. Lower values of soil $\mathrm{TN}$ and $\mathrm{C} / \mathrm{N}$ ratio under CT as compared with RT in all the cropping systems could be due to soil pulverization by CT, leading to accelerated decomposition of soil organic matter (Rahman et al., 2008), and possibly TN losses through leaching and plant uptake. Generally, the high TN in inoculated soybeanmaize rotation under RT can be attributed to low $\mathrm{C} / \mathrm{N}$ ratio of crop residues generated from soybean root and nodule biomass and in-season falling of leaves, as well as residues after harvest.

\section{Soil chemical fertility}

The lower values of soil chemical fertility properties observed in the soil under CT can be attributed to the effect of tillage on soil properties. This suggests that the soil properties under CT were less protected due to soil loosening and disintegration of soil aggregates, which subsequently accelerated cation losses through plant uptake and surface runoff, as well as leaching. This was equally supported by the low $\mathrm{pH}, \mathrm{CEC}$ and available phosphorus status of the study soil. The results are consistent with those of Rahman et al. (2008) who observed higher soil $\mathrm{pH}$ in RT than CT, as well as with Quadros et al. (2012) who reported $\mathrm{pH}$ values of 5.2 in both tillage and no-tillage in a subtropical Acrisol. The lower nutrients losses in soil under RT treatment due to slow mineralization could explain the lower accumulation of CEC in soil under CT than RT treatment. In contrary, similar study conducted by Obalum et al. (2011) under a degraded Ultisol in southeastern Nigeria revealed that tillage systems had no significant influence on any of the 
exchangeable bases and acidity in either of their two cropping systems. The CEC and \%BSat of the soil were significantly $(p<0.05)$ affected by tillage practices, with percentage difference of $6.93 \%$ for CEC and $4.17 \%$ for \%BSat. This implies that under $\mathrm{CT}$, higher value of OC is required, than it is with $\mathrm{RT}$, to raise the soil's ability to hold and exchange cations. Generally, the values of exchangeable bases obtained in this study were lower than the critical levels reported by Esu (1991) and NSPFS (2005). This could be attributed to low fertility status of the soil due to continuous cultivation and total removal of plant residues after harvest.

Significant differences obtained for cropping systems on available phosphorus, Ca, CEC and $\%$ BSat in soil indicated higher values under rotation and intercrop with inoculated soybean. This could be attributed to the effectiveness of inoculated soybean with rhizobium and rotation effect, which increases soil biomass, especially root and nodule mass production. However, the positive effects of rotation is often attributed to the improvement of soil biological and physical properties (Eche, 2011), and the ability of legumes to solubilise available $\mathrm{P}$ and highly insoluble calcium-bounded $\mathrm{P}$ by legume root exudates (Amapu and Babalola, 2006). The result suggested that maize/soybean intercrop would significantly cause more nutrient depletion and higher $\mathrm{N}$ uptake than inoculated soybeanmaize rotation in long-term practice. In soil, as the carbon dioxide concentration of the rhizosphere increases due to the presence of microbes and hair roots, the $\mathrm{pH}$ changes influence nutrient availability (Agbede, 2009). Also, within the cropping systems, the variability of decomposition of crop residues due to the differences in soybean-maize $\mathrm{C} / \mathrm{N}$ ratio would yield various exchangeable bases that influence soil chemical fertility. Soil organic matter was found to be related to all soil nutrients and its activity accounts for $95 \%$ of the soil chemical properties (Agboola et al., 1998). Thus, increase in soil organic matter would improve nutrientretention capacity and colloidal characteristics.

The result also showed that the soil under 120 $\mathrm{kg} \mathrm{N} \mathrm{ha}{ }^{-1}$ fertilizer applications was significantly higher in EA than other levels of $\mathrm{N}$ rate. This implies that application of $\mathrm{N}$ fertilizer above 120 $\mathrm{kg} \mathrm{N} \mathrm{ha}{ }^{-1}$ for soil productivity improvement result in loss of exchangeable bases due to increase in EA. Long-term application of fertilizers containing $\mathrm{N}$ might result in soil acidification (Belay et al., 2002) and influence the availability of $\mathrm{Ca}, \mathrm{Mg}$ and $\mathrm{K}$ for crop uptake. Increased content of exchangeable bases like $\mathrm{Ca}, \mathrm{Mg}$ and $\mathrm{K}$ in $\mathrm{N}$ fertilizer-treated plots, compared to no fertilizer treated plots, would have difference between input and output distribution within the soil solution. This is also established by the decreasing trend in the content of $\mathrm{Mg}$ in soil treated with $\mathrm{N}$ fertilizer, compared to the control (Mengel and Kirkby, 2001).
Tillage and Cropping Systems Interaction on Soil Available Phosphorus

Tillage and cropping systems significantly affected $\mathrm{P}$ content of the soil, which showed greater value in reduced tillage with rhizobium inoculated soybeanmaize rotation than other tillage and cropping system combinations. The low $\mathrm{P}$ found in CT under all the cropping systems could be attributed to low $\mathrm{pH}$ and $\mathrm{P}$ status of the soil. This implies that CT facilitated mineralization of organic $\mathrm{P}$ due to more exposure of organic matter in the soil to biotic and abiotic factors. Also, the high $\mathrm{P}$ in soil under RT with inoculated soybean-maize rotation could be attributed to positive residual effects of soybean, which improve OC content of the soil. The inclusion of soybean, especially inoculated, in the cropping systems under RT would promote the soil environment for $\mathrm{P}$ availability through increase of OC (Dahmardeh et al., 2010) and subsequent reduction of $\mathrm{P}$ immobilization.

\section{Tillage, Cropping and $\mathbf{N}$ Rate Interaction on Exchangeable Bases, Acidity, \%BSat and CEC}

The significant interaction found between tillage and cropping systems on $\mathrm{Ca}, \mathrm{Mg}$, and $\mathrm{EA}$, as well as \%BSat could be attributed to the agronomic practices like soil tillage and cropping systems, which influence the availability and utilization of exchangeable bases and acidity in the soil. The high value of $\mathrm{Ca}, \mathrm{Mg}, \mathrm{CEC}$ and \% BSat observed for soil under RT combination with inoculated soybean-maize rotation indicated that the presence of inoculated soybean in the cropping system under RT would improve soil productivity. Moreover, the high biomass production and ground cover provided by soybean, coupled with low annual rate of organic matter decomposition due to RT practice, would explain the higher accumulation of basic cations in the soil under RT than CT in all other cropping system combinations. A similar trend was observed between $\mathrm{N}$ rates and cropping systems, as well as with tillage. The results revealed that tillage and cropping systems with $\mathrm{N}$ fertilizer application influenced nutrient availability in soil and plant uptake. Their values were partly higher in RT, which shows initial increases and then decreases with $\mathrm{N}$ fertilizer rates, suggesting that mineral nitrogen, in addition to increasing the content of nitrate in soil, leads to changes in soil $\mathrm{pH}$ and other soil properties (Dragan et al., 2010). There were also significant increases in $\mathrm{N}$ content, humus and soil CEC, while the base sums and base saturation sums decreased with increasing $\mathrm{N}$ fertilizer doses, but under long-term effect. However, these revealed that integrated use of $\mathrm{N}$ rate and inoculated soybean-maize rotation under RT can significantly raise soil productivity than under CT and other cropping systems. 


\section{CONCLUSION}

The study revealed that conventional tillage lower chemical fertility status of the soil as compared to reduced tillage. The chemical fertility status of the soil index under inoculated soybean-maize rotation was significantly improved followed by inoculated soybean-maize intercrop with higher values of OC, $\mathrm{TN}, \mathrm{C} / \mathrm{N}$ ratio, soil $\mathrm{pH}$, available phosphorus and exchangeable bases. The least values of soil chemical fertility index were recorded for uninoculated soybean-maize intercrop. Results also shows that plots with $0 \mathrm{~kg} \mathrm{~N} \mathrm{ha}{ }^{-1}$ fertilizer application had low soil chemical fertility index as compared with other $\mathrm{N}$ treatment plots; suggesting that soil of savanna need $\mathrm{N}$ fertilizer for its optimum productivity. Significant interaction was obtained for tillage and cropping systems as well as $\mathrm{N}$ fertilizer application on some of the soil chemical fertility index. This implies that integration of inoculated soybean in soybeanmaize-based cropping systems in combination of tillage practices and nitrogen fertilizer application influences chemical fertility status of the soil which was agronomical better under RT at $80 \mathrm{~kg} \mathrm{~N} \mathrm{ha}^{-1}$ and those cropping systems with rhizobium inoculated soybean.

Acknowledgements This study was supported by the Institute for Agricultural Research, Ahmedu Bello University through support to staff in training.

\section{REFERENCES}

Adeboye M.K.A (2009). Microbial biomass and water soluble carbon as affected by cereal/legume rotation in a Guinea Savanna Alfisol of Nigeria. Nigeria Journal of Soil Science, 21 (1), 75- 85

Agbede O.O. (2009). Understanding Soil and Plant Nutrition. Printed in Nigeria by Petra Digital Press; ISBN: 978-978-900-087-6, 203-213

Agboola A.A., Ndaeyo N.U. and Kalu O.I. (1998). Soil fertility management alternatives to inorganic fertilizer use. In: O. Babalola, G.A. Babajide and S. Mustapha (eds.), Soil Management for Sustainable Agriculture and Environmental Harmony, Proc., $24^{\text {th }}$ Annual Conference of Soil Science Society of Nigeria; Bauchi 7-11 $1^{\text {th }}, 1-9$

Al-Kaisi M.M., Yin X. and Licht M.A. (2005). Soil carbon and nitrogen changes as influenced by tillage and cropping systems in some Iowa soils. Agric., Ecosystems and Environment 105: 635-647.

Amapu I.Y. and Babalola O.A. (2006). Response of some cowpea genotype to different rates of phosphorus in Samaru. Nigerian Journal of Soil Science, 16, 77-83

Amusat M.A., Osonubi O. and Oyetunji O.J. (2014). Effect of mycorrhizal, inoculation and crop rotation on maize growth and biomass production. Nigeria Journal of Soil Science, 24 (1), 183-190

Awujoola A.I. (1979). Soil Mapping and Soil Characterization Studies in the Zaria Area, Nigeria. Unpublished MSc Thesis, Ahmadu Bello University, Zaria, Nigeria. p. 148
Belay A., Claassens A.S. and Wehner F.C. (2002). Effects of direct nitrogen and potassium and residual phosphorus fertilizers on soil chemical properties, microbiological components and maize yield under long-term crop rotation. Biol. Fert. Soils, 35, 420-427

Bremner J.R. and Mulvaney C.S. (1982). Nitrogen-total In: Page A.L. (Ed). Methods of Soil Analysis, Part 2, ASA, Madison W1 595-624.

Campbell C.A., Biederbeck V.O., McConkey B.G. Curtin D. and Zenter R.P. (1999). Soil quality-effect of tillage and follow frequency. Soil organic matter quality as influenced by tillage and fallow frequency in a silt loam in southwestern Saskatchewan. Soil Biochem., 31, 1-7

Cassman K.G. and Pingali P.L. (1995). Extrapolating trends from long-term experiments to farmers fields: The case or irrigated rice systems in Asia. In: Agricultural Sustainability in Economic, Environmental and Statistical Terms, Barnett V., Payne R. and Steiner R. (eds.) Wiley, London, 63-84

Dahmardeh, M., Ghanbari, A., Syahsar, B.A. and Ramrodi, M. (2010). The role of intercropping maize (Zea mays L.) and cowpea (Vigna unguiculata L.) on yield and soil chemical properties. African Journal of Agricultural Research, 5 (8), 631-636

Dragan C., Elmira S., Veljko P., Darko J and Vesna M. (2010). Effect of long-term nitrogen fertilization on main soil chemical properties in Cambisol. Paper presented at 19th World Congress of Soil Science, 'Soil Solutions for a Changing World' 1-6 August 2010, Brisbane, Australia

Eche, N.M.A. (2011). Soil biological properties under long-term maize cultivation in Northern Guinea Savanna of Nigeria. An unpublished Ph.D Thesis submitted to the Department of Soil Science, Ahmadu Bello University, Zaria.

Esu I.E. (1991). Detailed soil survey of NIHORT farm at Bunkure Kano State, Nigeria. Institute for Agricultural Research Samaru, Zaria, Nigeria

FAO (2001). World Soil Resources Reports. p. 289

Gee G.W. and Bauder J.W. (1986). Soil particle size analysis. In: A. Klute (ed.) Methods of Soil Analysis $2^{\text {nd }}$ ed. No. 9 ASA Inc. Madison, Washington DC, 383-409

Giller K.E. (2001). Nitrogen Fixation in Tropical Cropping Systems, $2^{\text {nd }}$ edn. CAB International, Wallingford

Grossman R.B. and Reinsch T.G. (2002). Bulk density and linear extensibility. In: Methods of Soil Analysis, Dane J.H. and Topp G.C. (eds.) Part 4. Physical Methods. Soil Science. Soc. Amer. Book series No. 5 ASA and SSSA, Madison, Wisconsin, 201-228

Hendershot W.H., Laland H. and Duquette M. (1993). Soil reaction and exchangeable acidity. In: Soil Sampling and Methods of Analysis. Carter, M.R. (ed.). Canadian Society of Soil Science, Lewis publishers London. 141-145

Jou L., Paul P and Oplinger (1997). The corn and soybean rotation effect. Field Crops, 27, 426-428 http//corn.agronomy.wisc.edu

Karbozova-Saljnikov E. (2004). Soil organic matter status of Chernozen soil in Borth Kazakhstan: phosphorus fertilizers on soil chemical properties, microbiological components and maize yield under long-term crop rotation. Biol. Fertil. Soils, $35,420-427$ 
Mengel K. and Kirkby E.A. (2001) Principles of plant nutrition. 5th ed., Kluwer Academic Publishers, Netherlands

Nelson D.W. and Sommers L.E. (1982). Total Carbon, Organic Carbon and Organic Matter.In: Methods of Soil Analysis: Part 3 Chemical and Microbiological Properties, Bigham,J.M. (Ed.). ASA, CSSA, SAAJ, Madison, WI, pp. 961-1010

Nkhuzenje H., Mughogho S.K., Sakala W.D. and Saka A.R. (2002). Contribution of promiscuous and specific soybean varieties to soil fertility improvement and maize yield for smallholder farmers in Zomba District of Malawi

NSPFS. (2005). Nigerian Soil Fertility Rating and Thematic Fertility Maps. National Special Programme for Food Security (NSPFS), Abuja, Nigeria

Obalum S.E., Okpara I.M., Obi M.E. and Wakatsuki T. (2011). Short-term effects of tillage-mulch practices under sorghum and soybean on organic carbon and eutrophic status of a degraded Ultisol in southeastern Nigeria. Trop. Subtrop. Agroecosys. $14 ; 393-403$

Ofori C.S. (1993). Towards the development and technology transfer of soil management practices for increased agricultural production in Africa. Sustaining Soil Productivity In: Intensive African Agriculture; Seminar Proceedings, 25-32

Oikeh S.O., Chude V.O., Carsky R.J., Weber G.K. and Horst W.J. (1998). Legume rotation in the moist tropical savanna: Managing soil nitrogen dynamics and cereal yields in farmers' fields. Experimental Agriculture, 34, 73- 83

Okogun J.A., Sanginga N., Abaidoo R., Dashiell K.E. and Diels J. (2005). On-farm evaluation of biological nitrogen fixation potential and grain yield of Lablab and two soybean varieties in the northern Guinea savanna of Nigeria. Nutrient Cycling in Agroecosystems, 73, 267-275

Olson S.R. and Sommers L.E. (1982). Phosphorus. In; Page A.L., Miller, R.H. and keeney, D.R. (eds.). Methods of Soil Analysis, Part 2. Amer. Soc. Agron., 403-430

Omeke J.O. (2016). Effect of Tillage, Cropping Systems and Nitrogen Fertilizer Application on the Productivity of a Savanna Alfisol, Nigeria. PhD Thesis, Ahmadu Bello University Zaria, Nigeria

Omeke J.O., Yusuf A.A., Uyovbisere O.E. and Abu S.T. (2016). Assessment of microbial biomass carbon and nitrogen under tillage, cropping systems and $\mathrm{N}$ fertilizer rate in the savanna Alfisol of Nigeria. Acad. J. Agric. Res., 4 (5), 258-267

Oyinlola E.Y. and Chude V.O. (2010). Status of available micronutrients of the basement complex rock-derived Alfisols in Northern Nigeria Savanna. Trop. \& Subtrop. Agroecosystems, 12, 229-237
Petrickova N. (1992). Interrelationship between fertilization and the composition of the crop rotation. ActaAcademiae Agriculture ac Technicae Olstenensis Agricultural, 55, 41-47

Quadros P.D., Zhalnina K., Austin Davis-Richardson A., Fagen J.R., Drew J., Bayer C., Camargo F.A.O. and Triplett E.W. (2012). The Effect of Tillage System and Crop Rotation on Soil Microbial Diversity and Composition in a Subtropical Acrisol. Diversity, 4, 375-395

Rahman M.H., Okubo, A., Sugiyama, S. and Mayland H.F. (2008). Physical, chemical and microbiological properties of an Andisol as related to land use and tillage practices. Soil and Tillage Research, 101, 878-886

Rhoades J.D. (1987). Cation exchange capacity. Methods of Soil Analysis. Part 2. Chemical and Microbiological Properties. 2nd edition. In: Page et al., (eds) Agronomy. 9. American Society of Agronomy, Madison, WI, USA, 1490-1589

Sanginga N., Okogun J.A., Vanlauwe B. and Dashiell K. (2002). The contribution of nitrogen by promiscuous soybeans to maize based cropping in the moist savanna of Nigeria. Plant and Soil, 241, 223-231

Sanginga N. (2003). Role of biological nitrogen fixation in legume-based cropping systems: a case study of West Africa farming systems. Plant and Soil, 252, 25-39

SAS Institute Inc. (2009) SAS/STAT Users' guide. Version 8, $6^{\text {th }}$ edn. Statistical Analysis Institute, Cary, NC

Vanlauwe B., Bationo A., Carsky R.J., Diels J., Sanginga N, and Schulz S. (2003). Enhancing the contribution of legumes and biological nitrogen fixation in cropping systems: experience in West Africa. Grain Legume and Green Manures of soil Fertilizer in South Africa: Taking Stock of Progress, Proceedings of Soil Fertility Network Meeting. Vumba, Zimbabwe, pp. 3-13

Vincent J.M. (1970). A manual for the practical study of root-nodule bacteria. IBP Handbook of Methods. No.15. Blackwell Scientific Publication, Oxford

Yusuf, A.A., Iwuafor, O.N.E., Olufajo, O.O., Abadoo R.C. andSanginga, N. (2006). Genotype effects of cowpea and soybean on nodulation, $\mathrm{N}_{2}$-fixation and $\mathrm{N}$-balance in the northern Guinea savanna of Nigeria. In: Proceeding of $31^{\text {st }}$ Annual Conference of the Soil Science Society of Nigeria, 13-17 ${ }^{\text {th }}$ November, 2006, Ahmadu Bello University Zaria, Nigeria, $147-154$

Yusuf A.A., Iwuafor O.N.E., Abadoo R.C., Olufajo O.O. and Sanginga N. (2009). Effect of crop rotation and nitrogen fertilizationon yield and nitrogen efficiency in maize in thenorthern Guinea savanna of Nigeria. African Journal of Agric. Res., 4 (10), 913-921 